\title{
Ballad of Masonry in the Castle and Bridge as an Ethno-Cultural Differentiation between Ghegs and Tosks in Albania
}

\author{
Doc. Dr. Panajot Barka
}

\author{
Department of Greek Language, Literature and Civilization, \\ Faculty of Education and Social Sciences, University of Gjirokastra, Albania \\ pbarka@uogj.edu.al
}

Doi:10.5901/ajis.2015.v4n2p287

\begin{abstract}
The Speech takes for comparison two essential elements on which the muring ballad is based, in an environment with geographic and cultural heritage proximity, the "Bridge of Arta" and "Rozafa Castle". It aims at highlighting the meaning of symbolism in the ethno-cultural identification of respective communities. The comparative method is used in the field of folk creativity, sociology and anthropology. The bridge is treated as a symbol of passing, of relationship, of the possibility of integration. The castle as a protective means, but also as a means of separation and isolation. Conclusions: In the case of the Bridge, identity appears as an organic gestation of the autochthonous tradition with the newly created one, - a product of the opening and a result of various influences. The castle evidences the social organization based on tribes and the ethno-cultural identity as a vertical line that reproduces the autochthonous tradition at every level.
\end{abstract}

Keywords: Bridge, castle, identity, ballad, symbolism, tribes

\section{Introduction}

It is known and said that Albania is composed of two major ethno-cultural units, Ghegs in the North and Tosks in the south. Natural dividing line between them is the river Shkumbin that crosses the country from East to West and its flow is almost equidistant from the North and South ends. Between these two units, there are not only substantial differences belonging to the areas of language, social organization, traditional culture customary system, but also anthropological differences.(See: Çabej, 1974, Zojzi, 1962, Beci,1988, Gjinari, 1977)

The purpose of this article is to highlight the ethno-cultural differentiation between Gegëri in the northern Albania and Toskëri in the Southern Albania. The latter coincides with the old Northern Epirus and the new southern Epirus. The perspective chosen in this article is based on cosmogony elements of popular and cultural consciousness, such as the sacrifice and the carriage of this act in both ethno-cultural symbols, such as masonry in the bridge and in the castle.

\section{The Sacrifice}

Central idea of basic constructions in human relations with the surrounding environment, terrestrial or celestial, constitutes "primitive sacrifice". In other words, inanother sense, there is no achievement, or creation without sacrifice.

In the dimension of historical anthropology sacrifice was treated as a potential solution to problems that primitive man dealt with. Through this act, sacrificial man aimed communication with God, receiver of the sacrifice, which, in the self-understanding of primitive man, he had control over his unaffordable phenomena.

In this report, the man felt the need to donate to gods the dearest thing which was his own life, identified with his own blood. Being blood carriers of the "living soul",his sacrifice was considered the most sublime gift for the gods. It is understood that such was the alleged aspirations in return. (In our case the construction of a bridge, or a castle, which, as we said, constitutes the basic element, the identityof a community )

At the same time, the man came to realize that if ordinary death constituted the impetus of life, then the violent death had this feature. But not every kind of violent deaths. This featurewas won by the violent death with community participation and based on a ceremony, which presupposes ritual-ceremonial extermination that who self-sacrifice. In turn this means that the martyr accepts this act or at least does not oppose it.

The philosophical core of the sacrifice act is related to the fact that it is used as an efficient tool to avoid collision and internal degradation of the community, to export it out to him, in order to preserve and strengthen the practice of 
group unity. In essence, it constitutes the mechanism of existence and moulding of social community. This is also the basis of sacrificial religion. Another characteristics Christian myth according to which God is not a victim, but the victim becomes God, he is God himself, who on the one hand saves us and ensures the unity of sacrificial community, and on the other hand resuscitates. By the time he resuscitates he saves the community from the guilt of sacrifice act.

\section{The Bridge}

The starting point of the symbol should be sought in the ancient Greek mythology. "The bridge of hairs" of Hadi, which connected the banks of three rivers, which divided the hereafter with the living... The bridge was symbolized through Iris who possessed messenger role by the gods. Rainbow was considered a natural symbol of the bridge by her. As such, the was selected among the first symbols of the primitive society.

According to René Guenon, Pontifex in ancient Rome was a "bridge builder ", ie he who, as the etymology of the word means, mediates between two separate worlds. Pontifex name today is inherited in the highest position of the Catholic religious hierarchy, that of Pope, the mediator, in the role of a certain bridge between earthly and the heavenly world, God and man.

It represents the division between the opposites, the pass from celestial to terrestrial and the power of the soul. It is the symbol of sublime devotion, the superiority, divine mission, the power of spiritual and earthly world.

In popular culture, philosophy, theology, politics, and in daily practice, the bridge represents the symbol of transition from one condition to another, the change or the desire for a change.

In political and social philosophy of modern history, the bridge as a symbol obtained a multi dimensional concept."Build bridges" means "ensure the best outcome that human cooperation can achieve." On one of the sides of Euros bank-note is a bridge which belongs to a certain period, the symbol of communication between the peoples of Europe with the rest of the world, and it is fair to say that Europe lives by adding the number of its own bridges.

\section{The Castle}

Unlike bridges, castles got the right of the symbol and conceived as such with heroic epos. It reached the poly semantic and stable status ranging from the early Middle Ages. It is a complicated symbol originating from home, protective fortress and walled city. (It must be remembered that in the Byzantine Empire, the example of Constantinople, all the cities were built within the walls of a castle or defensive fortifications.) In this context, the encircled city, or closed, castles appear as symbols of the soul in its importance of challenging.

In general castles were built on top of a mountain or a hill, an additional element in its symbolism of resistance. Form, appearance, colour, dark and lit places have a special role in determining its symbolism, associated with spiritual, vigilant and armed strength. The meaning of the symbol of the Castle as "The place of the hereafter", or "the place that leads to another world", is visible. There are also "bright castles", which show the liberated side of the same vision.

In Albania, according to Shaban Sinani, "castle, "...apart from the symbol of resistance, is also an expression of a sedentary population associated with ancestral lands..." (Sinani, 2005)

\section{Particularity of Albanian Dilemma: -The Castle or the Bridge}

The Bridge, like the castle, together or separately, with the status of identity and ethno typical symbols, mutually accompany the identity of every nation as their carrier in every time. Incarnation in this function is achieved through maximum engagement of popular, creative consciousness, as cultural and artistic conscience. As such, the bridge or the castle, deserves human sacrifice or offering conforms to their importance.

The above mentioned definitions adjusts particularly the ethno-cultural realities of the Balkan peoples. These realities also show that every nation in the sense of the nation, selects the sacrifice in the bridge, or that in the castle, or both. This kind of selection has remained unchanged in time and space, which means also that every nation, or community, the selection of edifice waiting for sacrifice neither happens as a result dilemmas, nor varies depending on the conditions and historical circumstances. Thus, according to the Bulgarian variant sacrifice was done for the construction of a without name fortress, to two Serbian variants sacrifice was done for the castles and the town of Skutari. In other Slavic variants sacrifice was required to build a monastery, or a city, or a bridge, or other edifices. To the Romanian variant sacrifice was done in the bridge. Concerning the sacrifice in the bridge there are also Greek variants led by the two well-known ballads that of Arta Bridge and Triha Bridge (the hair). (It is important to emphasise that 
sacrifice in the bridge is a priority, in the reality of South eastern Europe, and it is found in 11 languages.)

Contrary to this right adjustment, at least at the Balkan, philological opinion of Albanians offers a different approach to their own reality. According to them, sacrifice in the bridges and castles does not fit to the reality of the two units (ghegs and tosks) of the Albanian people, but constitutes the unity of a diachronic dilemma, which shows the differentiation between the north and the south depending on the historical conditions imposed mainly by external factors, at times takes priority the sacrifice in the bridge and another time that in the castle. This dilemma is conceived not only as a tragic perturbation, but also as a determinant aspect of the ethno typical hinge offering sacrifice in the castle. 2005)

This type of interpretation finds its explanation in the ascertainment (findings) of Prof. Sinani Shaban. (Sinani,

"There was no doubt that, it was a hectic choice between coexistence hand and the sword and duel, between the opening and closing, precisely, because of the dismal horoscope that time reserved to Albanian people from antiquity until recently. Rich West for the East and exotic Orient for the West, this separate corner of Europe has experienced the fate of the junction and has also expressed its traditional culture. As in the course of history, even in their songs people wrote lyrics about them, whenever the winds of peace and friendship blew. But too often they were locked in the castle, even with three or four enclosures, because scary winds have taken the place of peace. These changes are linked not only with the traces of years, but also with the flow of historical ages... restriction and existence of people have widely brought the sacrifice in the castle and in the bridge ....."

A thesis about this diachronic dilemma, ie between the bridge and the castle, is treated by its supporters as a truth that does not accept verification, as an axiom. Its supporters also base their judgements on current Albanian reality and ideology. The aim is to present ethno-cultural homogeneity of the Albanian people in the territory of the state today, to win a diachronic dimension to the trend in the past and in a geographical space that complies with the spread of the Albanian element supported by the power of the Ottoman Empire at the time of Balkan invasion by it.

A basic argument in support ofAlbanian axiom of philology and ethnology is the statistical mapping of masonry variants in the bridge and in the castle. According to the ethnologist Shaban Sinani, there are 150 versions of the ballad of masonry. Of these 90 referring to sacrifice in the castle-fortress and 60 to sacrifice in the bridge. A claim arose in parallel for a simultaneous medley of them along all Albanian geography. "There are songs for sacrifice in the bridge in the east ,south and middle of Albania, and songs for sacrifice in the castle exist from the Northwest, in Shkodra, Elbasan and to the Coast ". (Sinani, 2005)

\section{The Against Argument}

The fact that there is not a real scientific study, which will prove this thesis, or will shed light, if there are social, historical or anthropological reasons to argue the split position of the Albanian ethnic and cultural identity expressed in sacrifice ballads or masonry in the bridge or in the castle.

The simultaneous existence in the modern history of Albanian ballads of masonry in the bridge and in the castle makes it impossible to talk about a unique choice in the form of a dilemma once in the bridge an another time in the castle, for all, or for an area of the actual Albanian territory, but helpful for stable and unchanging solutions of ethnocultural diachrony of North and South, in Gegëri and Toskeri. Furthermore, it allows to talk about the symbols that express an ethno-cultural differentiation between these two constituent units of the Albanian population.

Northern Albania is identified with the castle, the fortress and the tower, It is not only the symbol of defence, stability and sedentary but also the symbol of isolation, conservation and security. It is the product of a closed society traditionally based on the social organization, the patriarchal family and the tribe. Internal cohesion of the ethno-cultural society is achieved through confrontation with third parties. "Albanians, above all, those of the northern highlands, are, even in our days, those who have been thirty centuries ago, shepherds and warriors, who think, feel, live and die as heroes of Homer," says Pasko Vasa, one of the prominent erudites' of Albanians in the nineteenth century. (Vasa, 1887)

Sacrifice in the bridge in the south of Albania is Identified with an open society, in which the separation phenomenon of big patriarchal families happened times ago and basic ethno cultural elements are enriched with other multicultural elements. On the other hand, the South is part of a mythological and literary tradition, in which the sacrifice in the bridge had a primary role in cosmogony of the ancient worldview and in the relationships between the two worlds, the man and the nature, the man and the gods.

Ismail Kadare, a well -known writer whose origin is from the south of Albania cites that one of the reasons why his creativity is inclined from the legend and the myth is that: "Firstly, it is approaching in antiquity, and that Albania is a 
country that is bordered by Greece and has been enlightened (influenced) by Greek literature". (Kadare, 2004)

Also, ballads of masonry in Albania have as an archetype respectively the Arta bridge in Southern Epirus (Greece) and the Rozafa castle, near the city of Shkodra in today Northern Albania. So, it is about archetypes that express differentiated realities, even the clearly different ethnocultural ones.

Following this approach should also be noted that in the Albanian mentality, bridges and castles are neither complementary between them. On the contrary, they often turn to the personification of relations between the two ethnocultural identities that express and symbolize. It is known for example, that the Albanian mentality (mainly northern) bridge metaphor helps develop negative connotation: "If you become a bridge ,all the people will walk on you", "on the bridge crosses the good and the evil", "do not bridge" "bridges are needed more for the others than for themselves" etc."Relations between the wall and the bridge in the songs of Masonry, says prof. Sh. Sinani, are both expressions of hearth and world connections, ethnicity and humanity, "the own" - "the strange" (Sinani, 2005)

This means that the concept of the bridge is not connected with the national Albanian identity, an identity which in the history and ethnology of the Albanians people is promoted through the symbol of the castle.

So, as it will be seen below, it comes to sustainable differentiation between ethnocultural diachrony in the north and south, Gegëri and Toskeri, while the relationship between them until late were considered as antagonistic. "Around the middle of the nineteenth century Johann Georg von Hahn noticed that between Ghegs and Tosks existed an antagonism inherited from their ancestors" (Clayer, 2007)

Precisely, these differences in identity are reflected and stored lively in different ballads whose subject have to do with masonry, the bridge or the castle, regardless of the times, especially modern ones, which has smoothed many of these differences.

\section{Social Reasons that Ascertain the Sacrifice in the Castle}

Ballads of masonry in the bridge and in the castle mutually identify the north and the south of today Albania', or Gegëri and Toskëri for a variety of social and anthropological reasons, the traditional structure of the organization of life and relationships with the third parties.

There is no doubt for every foreign or domestic reseacher, that the mountainous areas of northern Albania still nowadays have a conservative character. And this is mainly due to the nature and the need for a permanent confrontation with the thirds, the foreigners, people outside the tribe or people outside homogeneous tribes. (Sinani, 2005) Both, these factors imposed a new way of social organization, which guarantee survival in time, according to a reproductive development of oneself in all directions and levels, that quite often it gives the impression that this population "is the disposal of the closing, the self-sufficiency"; (Sinani, 2005) that "..Albanians called for help the mountains...", says Mazower Mark. (Mazower, 2000) According to Kadare (Kadare, 1980) the preservation of this development way is closely related to the closed way of Albanians living in the mountains. "In the mountains, there are old codes, indigenous things, tradition, habits that come from antiquity. The canon, the code of vendetta, blood price etc." (Kadare, 2004) "Ancient ways of lifestyle in the material and spiritual culture, are not preserved so faithfully by the indogermen peoples... Only the Albanians can talk about a sedentary tradition and unabridged one since the ancient times..." (Çabej, 1994)

Also, Hahn explains that isolation is the main factor that Albanians had preserved their ancient customs intact (the law of vendetta, revenge, tribal organization) and remained in "a degree of culture", that the Romans and Greeks had left behind when they had entered into history. (Hahn, 1854)

According to the ethnologist Zojzi Rrok "typical tribal system existed only in the Northern Albania, on both sides of the river Drin. Furthermore, in the south, in the provinces of Dibra, Mat, in the mountains of Kruja and Tirana, the society was structured in small tribes or tribal branches, while in the fields situated in the West (coastal areas) and in the East, Kosovo, Macedonia, the society was organized in the family, which originated from different tribes, linked to each other by territorial units, called bayrak." (Zojzi, 1962)

It is necessary to mention and emphasise that the preservation character of the northern Albania was linked to their militant character. On the other hand, it is known that the symbol of the castle originates from home. In northern Albania the house has been identified with the tower, a family castle, as an adaptation to survive in conditions of resistance, siege, war and hostility, to protect themselves from revenge, vendetta and slav. The personification of this reality is the figure of ahighlander in Kadare's creativity. The rifle is a continuation of his vertebral column and into his tower two things had extreme importance for the continuation of life. The woman giving birth and the shooting rifles. 
"And for the Albanian were

Equally expensive either:

The shooting and the child. "says the poet. (Kadare, 1964)

This form of life regulation in the north, in parallel constitutes "the most simple expression of collective individualism" (Çabej, 1994), as the value of internal social cohesion, on the basis of which ,lately will be structured the national identification bed ..

As Hasluck said, "...If an Albanian was killed by a Slavic, then in retaliation an ordinary Albanian would kill awhatsoever Slavic. In this way crime will set against each other Albanian and Slavic families. This feeling was so strong that, although there was no special love between ghegs and tosks, no Gheg would allow a Slavic to kill a Tosk without asking then to kill a Slavic by himself. Being less combative tosk did not feel such an impetus" (Hasluck, 1954)

\section{But when Was Formed the Ballad Archetype of Masonry in the Castle?}

Based on the fact that the ballads are a direct continuation of ancient myths, the question should be asked differently. How is created the masonry ballad of Rozafa Castle? There are objective obstacles that do not create the necessary space for such an explanation, therefore, we remain on the need to answer the initial question.

Firstly, Marin Barleti XVI century European humanist from Shkodra, while writing about the siege of Shkodra, spoke about the existence of popular legends about Rozafa, and did not mention masonry ballads .

The argument from Sh. Sinan (Sinani, 2005) that the pagan spirit of the legend of masonry was unacceptable from the church, was avoided by him, it could not stand. Barleti was a humanist and it is known that humanity is the first step of removal of religious absolutism of the Middle Ages, and sets the man on the spotlight. On the other hand, the church had adopted its ideology of sacrificial rite in the fundamental law of its doctrine, because as it was said Christ resurrection occurs after his sacrifice.

Secondly, Ballad of masonry in the castle is not found in Arbereshof Italy. It is known that they moved to southern Italy in the fifteenth century. They carried and maintained both the cycle of heroic songs and other ballads, but not the type of masonry ballads of in the castle, much less that of masonry in Rozafa castle. It is not also found in that part of Christian Albanians, who after the death of Scanderbeg in the end of the fifteenth century, under Venetian call went down to Himara to resist to the Ottoman occupation.

Thirdly, masonry ballad of Rozafa Castle, surprisingly does not attract even the attention of Prof. E. Çabej, even when referring to folk songs to interpret ethno-genesis of the Albanian people. In his comparative study dedicated to this topic "Albanians between West and East," he notes that excluding Greece, the new, popular epic in Balkan stems from XIV century. It was born and developed in the confrontation with the Turks, and is under the influence of the Greek hero of heroic epos, Digenis Akritas. (It means Byzantine empire hero who fights to protect its ends, -akritas border - from the Arabs, in the Near East before IX century.)

In Albania, unlike other Balkan peoples heroic epos, consist of muhammadan heroes fighting to protect the borders of the Ottoman Empire against the enemies of Christians. They changed not only their religion but also their heroes' names and fighting direction. With this argument Çabej recallsus the famous assertion that the Turkish Empire occupation of lands of Byzantium became the inheritors of the Byzantine culture and adapting it to its own interests.(Çabej, 1994)

Apparently, this is the fate of the masonry ballad in this castle. Its construction goes deep in centuries and perhaps for this it was crowned the ballad of masonry. A similar hypothesis can also be brought for the name of the castle Rozafa. A variant indicates that the name is composed of the names of two brothers, Rosa and Fa (siblings) its founder. Another version says that Rozafa was little brother's wife, a bridge builder who sacrificed himself. There is also a third option that links the name of the castle with Jewish builders of an ancient religious building, coming from Israelite Rozafa.(Sinani, 2005) But there are many toponyms of the type "Rozafa" in the Islamic world.

Çabej also noted that "The songs here do not have organically a long life. They crucify or eradicate each other... " (Çabej, 1995) and continues"... Of course, from the old Roman period to the early medieval there is nothing left in the songs..." (Çabej, 1995) And he concluded by saying that" popular poetry did not influence in the national awakening of Albania, he had no connection with this new reality. (XIX century) So it was imported from the cultural people and served as an ideology in meeting the immediate interests of a person or a group. " (Çabej, 1995)

"In social-historical terms, these songs, (the cycle of Muji and Halili) talk about aristocratic gentlemen and courageous men and that seems to coincide even with the style, which never becomes banal, but shows a certain nobility of form and thought" (Çabej, 1995) 
This cycle was found by Çabej in the "Serbo-Croatian land and northern Albania, with bifurcations from Bulgaria". (Çabej,1995) To claim that "As these songs arepresented in Albanian and Bulgarian versions we see the impact of the Serbo-Croatian folk poetry at least in the metric view". (Çabej ,1995)

These arguments indicate a relatively new stratification of masonry ballads in the castle.

From the above statements we can draw three conclusions. 1- Songs of masonry in the castle, among them the central ballad of Rozafa, are created after the fifteenth century. 2-arerelated to the Turkish invasion. 3- Within the logic of folk creativity, they were carried from the Byzantine reality and folk traditions of neighbouring peoples from high social structure and their service, but separated from people.

\section{In Favour of the Lack of the Sacrifice Dilemma, in the Castle or in the Bridge the Geographical Scope Plays an Important Role in these Mutual Ballads}

Supporters of the thesis that masonry ballads in the castle, does not exist only in the north, are referred to statistics of geographical scope, which show that, except the North and the Northwest, in Shkodra, this masonry ballad was found in Elbasan. Variants of the masonry ballads in the castle were found even in coastal areas. As emphasised above, this fact shows the diachronic homogeneity of Albanian population today and the castle serves as its symbol of sacrifice.

However, its Albanian sources indicate that on the one hand there are no ballads of masonry in the bridge in northern Albania. And on the other hand, shaping the archetype of the ballad of masonry in the castle belongs to the period after the fifteenth century and that this process is related to the presence of the Ottoman Empire and the strengthening of its power through Albanians. "As a Muslim, Albanian was an ally and equal to ottomans, who protected him against the abuse of Slavs and Greeks" (Vickers 1995) Kadare, also supports the same thing. (Kadare, 2010) This also means that the process of Muslim among Albanians was not just a religious problem, but was associated with broader ethno-cultural phenomena.

The same factor, the presence of the Ottoman Empire, should be seen as a determining factor in the favour of the centrifugal tendency of the North Albanian population, in different directions especially to the South "Ottoman Empire brought the Albanians to the front and ended their migrant..." (Çabej, 1994) Çabej proves so, the British researcher on issues of Epirus, Hammond, who says "... Albanian speakers of Epirus are descendants of Albanian invasions, who came to the South over the period of the Turkish Empire and colonized mainly coastal valleys " (Hamond,1971)

In this perspective the argument that there is a similarity between ghegs in the north and lebër in the south(in today's Labëria region), as an indicator of diachronic, ethno-cultural, Albanian homogeneity is easily refutable.

According to Baron Nopcsa's, to whom Çabej referred in his book "The Albanians between the West and the East", the name of labëve originates from the name of the Illyrian tribe Labeates that lived near Shkodra's Lake. (Çabej,1994) Çabej wrote that Lebërs came to Toskeri as a wedge and split that ancient unit. (Çabej, 1994) Also, Nathalie Clayer, said that large patriarchal families with 80 members or more corresponds in the South, in Laberi. (Clayer, 2007) This fact is proved by the efforts of Ismet Elezi to find similarities between the canon of Lek Dukagjini and Common Law in Laberi. (Elezi, 2002) Shaban Sinani insists that Lëbërs narrowed the geographical area of Himara not before the eighteenth century. (Sinani, 2004) Preservation of tribalism in Laberi, according to Çabej, is not linked to the nature, as much as it is linked to their northern origin and adds that, "In societal terms Labe are bearers of weapons in South..." In supporting this fact Nathalie Clayer adds that about 30000 people from Laberia were lined up in different military troops of the Ottoman Empire. (Clayer, 2007)

So it's a mass migration from the North to the South, in the heart of Toskëri, or Epirus, even at a late period, and in parallel the bearers of habits and customs in the ensemble of folk material and spiritual culture in the new settlements. Arguments are enough to convince even the most sceptical person that these are the reasons why we find variants of masonry ballads in today's castle in southern Albania which are mostly related to Laberia.

\section{The Argument of Masonry Ballad in the Castle with Stretch on the Coast}

Even more interesting are the facts of identifying the masonry ballad in the castle in coastal areas and why they are not related to the southern culture. It was argued that in the legend of masonry in castles, in the territories inhabited by Albanians constitute even the new borders of the Ottoman Empire, in which Albanians Muslims, as Kadare claims constitute its real power of this invading empire. Ballad of masonry in the castle, is precisely evidenced in these boundaries, which make up simultaneously the line of confrontation with the world of Christian peoples in the Balkans and Europe and that this confrontation was intense. Venice, for example, had achieved to have under its control a large 
part of the coastline in Albanian borders of the Ottoman Empire and that many other western factors pressured to expand their influence here. Consequently ,the castles on the seashore constitute durable protective fortresses of the Ottoman Empire to the Christian forces. With this mi confrontational mission Çabej links "Muslims" with heroes of epic Albanian songs.

So, the main hero of the north legendary epic George Elez Alia , fighting against Bajloz emerged from the sea to humiliate the hero. It is known that Bajloz name leads to the Latin term "baiulus", which was used not only for diplomatic representatives of Venice in Byzantine Constantinople, but also for them of the Ottoman empire. It is more than reasonable that the Albanian community organized under Ottoman models, had to develop the traditional culture in the service of the interests of the empire. It is equally logical that in this process the adoption with the past experience was a necessity, according to which, from the sea came all evils - the Roman conquest, the Crusades and now the Western expansion.

\section{Kadare, the Symbol of the Bridge and Castle and the Differentiation between North - South}

This North-South differentiation through mutually sacrificial symbolism in the castle and bridge, can be easily mentioned in the writings of the well-known Albanian writer Ismail Kadare. Bridges and castles are widely included in his literary production of the researcher. If kadariane aspiration is related to his attempt to give antique and western identity toAlbanian ethnogenesis, as a theory and literature, these symbols will constitute the vertebral column(backbone)of his aspiration.

However, what is observed is that Kadare refers to the symbol "castle" (fortress, tower), even in historical terms, its definition on one hand, has to do withensuarance, provision of support and political sustainability and on the other hand ,aims at identifying the "sedentary" strength of ethnic identity.

When Kadare refers to "bridge" his purpose is "to create the image of "another Albania", which differs greatly from that seen with the eye, "...the image of the absent Albania and finds it "in the traditions of Albania", in the stage of history when the country caught up with its neighbors across the Adriatic. (Sinani, 2005)

\section{The Bridge identifies the South}

Kadare is not interested in this differentiation but was guided by his intellectual consciousness, a natural communication with the reality of tradition. He caresto highlight the fact that the tradition of folk poetry for peace involves two important aspects. Initially the existence as a literary archetype embodied in the Greek literature,secondly, it was known as thousands of year reality in which the existence of the bridge was identified as the ethno-cultural,political and economical development of a country known as Epirus.

Referring to Kadare' works it's normal to come to conclusion that South Albania today, identified diachronically with Epirus, is also identified with the bridge. It is known that in this region was build the first bridge of the mythological cosmos: -Trihino Jofiri (Hair Bridge). The souls crossed though it to the hereafter, in Had, which geographically is located in the ancient Epirus. Three rivers of mythological Hadi crossed that bridge, Akeroni, Periflegjethon and Kokitos.

This tiny bridge likea hair, that in Mythology linked the two Worlds, that of death and life, was appointed to connect two banks on many rivers, streams and abysses. (Romaiou, 1979)

The second, real bridge is that of Arta with a long history of buildings and destruction which began in Roman times and continues with the construction of the road Egnatia, the Dhespotati of Epirus, the Turkish occupation, the Patriarchy of Ioannina and until nowadays. It is not known at what time the bridge of Arta was identified with the ballad, which is based on another element of ancient Greek mythology, that of sacrifice. But the importance of the bridge ballad that deserved offering as a sacrifice made it a famous bridge and was appreciated for the value of identity.

There is also another point that should be considered. According to their strategic geographical position Toskeria and Epirus in the ancient times served as the main crossing intensive roads from North to South and from West to East and vice versa.

Their geographical position served as a bridge for crossing the Greek tribes, but also the Mycenaean culture. Through this "bridge" was conducted cultural Greek expansion after the Trojan War in Illyria and Macedonia. The Peloponnesian War in the second half of the $\mathrm{V}$ century BC. This area became the heart of the two bridges of the biggest empires of antiquity, that of east with birth of Alexander the Great and that of West with Piro of Epirus. Geographical position here became the bridge of the Roman Empire to spread roman culture across Southeastern Europe. And the first global size bridge that linked the two most important capitals of the world, Rome and Constantinople passed here. 
This land became the bridge to Latin crusaders and the place that sheltered Byzantine after the first collapse of the Constantinople in 1204. This role gave the right that during the centuries of Ottoman occupation to coexist five languages and cultures. It is the bridge that accepted every passages and crossings, peaceful and antagonistic coexistence.

It means a Bridge that firstly seems to be used by the others. In fact quite the opposite happened. In this roleit identified the existence and development of its own and gave itself the right to precede the historical developments in the region, without ever losing its importance. And for this role had to sacrifice for its foundations a lot of energy, blood and efforts.

But this great bridge, was cooked with nature, geographical location, ethno-cultural identities, and practically required hundreds of other concrete bridges, small and large, for all times and for all crossings and coasts. 139 traditional stone bridges from Roman times until the nineteenth century in southern Albania are described in the book of Spiros Mandas. (Mandas,2012) City of 100 bridges, is characterized Permet because the Valley of Vjosa, from the place that it joins the river Drino, up to Three Bridges, in the border of Greece, are numbered over 100 bridges of different dimensions and periods.

Well ,this wide spread, during all this time sometimes contrary to the nature, certainly would exclude the symbol of the castle and accept that of the bridge, as a symbol and a reality.

\section{Conclusion}

As a final conclusion can be said that for the Albanian reality we can not talk about a selected dilemma, between the sacrifice in the bridge or in the castle, a consequence of historical and political conditions, but for a choice in space and time, which carry the ethno cultural diachronic differentiation between Gëgëri and Toskëri

In the case of the Bridge, the identity appears as an organic gestation of autochthonous tradition with newly established tradition-the product of openness and consequence of various influences.

The Castle identifies cultural identity as a vertical line that reproduces autochthonous tradition in every level.

\section{References}

Academy of Sciences of Albania, (2004). Himara in different centuries, Tirana.

Clayer, N. (2007). The origins of Albanian nationalism, La naissance d'une nation majoritarirement muslumane en Europe ", Paris.

Çabej, E. (1994). Albanians between theWest and East, Tirana.

Elezi, I. (2002). The common law in Laberi, Tirana.

Hahn, J., (1854). Albanian studies, v.1, Vienne.

Hammond, N.G.L. (1971). Epirus, v. A, Athens

Hasluck, M. (1954). The Unwritten Law in Albania, Cambridge University Press.

Hobsbawm, E. (1992). Nations et nationalisme depuis 1780. Programme, mythe, réalité, 7, Paris.

Kadare, I. (2004). Surrounded World, 13/04/2004.

Kadare, I. (1980). The Autobiography of people in verse, Tirana.

Kadare, I. (1964). Why do these mountains think?, Tirana.

Kadare, I. (2010). Divergence, on the report of Albania with itself,Tirana.

Mandas, S. (2012) Petrina Jofiria sti Boreiolpeiro (The stone bridge in Northern Epirus), Athens.

Mazower, M. (2000)., The Balkans, London.

Romaiou, K. (1979). To dhimotiko tragoudhi, problimata katagogjis kai tehnotropias, (Costa Romaiou, Folk song, Problems of its origin and creation), v.l Athens.

Sinan, Sh. (2005). A folder for Kadare, II, Tetovo.

Vasa, P. (1887). Albanian grammar for use by those who want to learn this language without the help of a teacher. London, Trübner.

Vernicos, N. \& Dhaskalopoulou, S. (1999). Stis aparhes tis Neoelliniqis Idheologjias, (At the beginning of the new Greek Ideology) Athens.

Vickers, M. (1995). The Albanians, a modern history.

Zojzi, Rr. (1962). Provincial division between the Albanian people (The Albanian Ethnography I). 